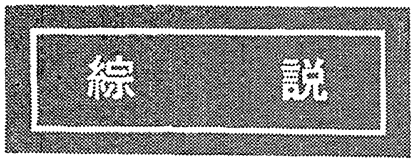

\title{
adrenaline 受容体と血管反応
}

\author{
戸明昇 ${ }^{*}$
}

\section{はじめに}

薬物受容体 drug receptor は生体において薬 物が最初に直接結合する細胞構成分子であると 定義されている1). しかし，楽理学の領域では 薬物と結命することによって細胞ならびにその 集合体である效果器に特異的な機能变化をもた らす場合に限って薬物受容体の名称が使用され る(1)3). 楽物と結合しても作用を現さない場合 には（例えば血漿，赤血球，分解酵素との結 合)，これを drug acceptorまたは silent receptor と呼んで区別する1)。自律神経支配㵴器の薬物 受容体研究は過去数十年にわたって薬理学, 生 理学ならびに生化学研究者の興味を集め, 幾多 の有意の所見が報告されているが受容体の実体 はまだ把えられていない。

血管平滑筋は標本作成が容易であり，安定し た薬物反応を䒩起し，薬物用量一作用曲線が容 易に得られ，かつ薬物感受性が高いなぞの理由 から特に adrenaline $\alpha$-受容体ならびに平滑笳 の収縮機構研究の目的に古くより使用されてき た。しかし，電気生理学的検索が困難であり， 酵素および生体活性アミン含量が比较的少なく 抽出操作も簡単でないなど生理・生化学的研究 発展の障壁もあって血管平滑筋の基礎的研究は まだ十分の成果をあげていない，従って，ここ に述べる adrenaline 受容体学説ないし仮説は血 管標本のみならず心臟, 消化器, 泌尿器その他 の藏器組織より得られた所見を総合して組み立 てられたものである。この際, 薬物の棈造活性 相関 structure-activity relationship が主要な手

* 京都大学医学部楽理学教室
がかりとなる、本稿では血管の adrenaline 受容 体学説の紹介に加兄て，興酉収縮連関，血管収

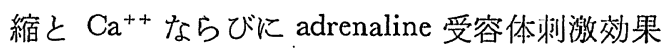
の实際について述べることにする。薬物一受容 体結合の分子楽理学的解析については Ariëns ${ }^{4}$ および Furchgott5) の記述を参考にされたい。

\section{I. adrenaline 受容体}

Ehrenpreis たち6) は薬物受容体が充たすべき 条件として以下の四つをあげている（1）特定 の生体内および外来物質と化学的に結合し得る 高分子物質であること（2）生体内物質に刘す る作用点の特異性および同物質との結合によっ て生ずる反応は出生前から遺伝的に決定されて いること．（3）特定の生体内または外来の物質 と結合して特翼的な conformation 変化ないし周 辺の状沉変化 (外来刺激の增減) を落起し，そ の結果一連の物理化学変化を誘発して反㐫をひ きおこすこと.（4）活性物質との結合によって 㤰起される反応は同物質の共有結合の消長と関 係なくおこること.

血管の adrenaline 受容体は Ahlquist ${ }^{72}$ 以来 2 つに区分される。すなわち，phenylephrine 扰よ び methoxamine によって刺激され収縮を誘発 する $\alpha$-受容体と，isoproterenol によって刺激さ れ弛緩を誘発する $\beta$-受容体がそれである。 $\alpha-$ 受容体刺激効果は麦危アルカロイド8), dibenzyline ${ }^{9)}$, phenoxybenzamine, tolazoline, phentolamine ${ }^{10)}$ などによって特異的に遮断され， $\beta$-受 容体刺激効果は dichloroisoproterenol11), propranolol12)，MJ 199913)などによって拮抗される。 noradrenaline 拈よび adrenaline は両受容体刺 


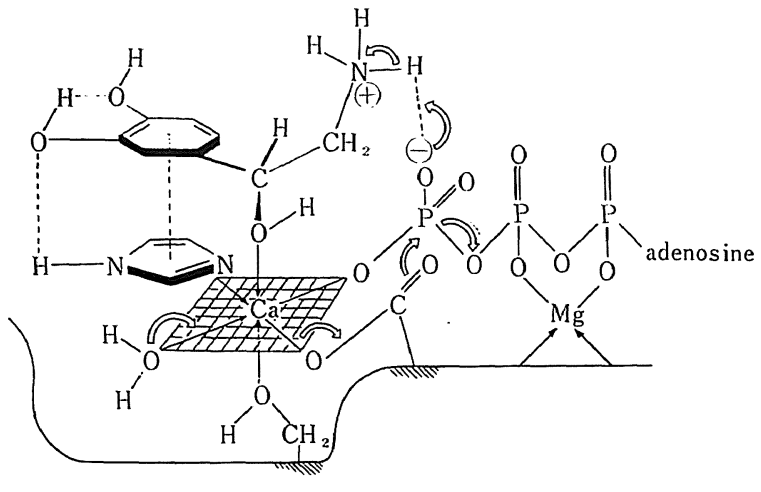

図 1 adrenaline $\alpha$-受容体模型 ${ }^{15)}$

激作用を有し，血管の種頪によって（血管の有 する優位受容体の相違によって）収縮または弛 緩を萀起する。また，遮断薬処置によってしば しば作用の近転が認められる。

\section{(A) adrenaline $\alpha$ 受容体学説}

1. 細胞膜 ATP・ATPase が受容体であると する Belleau14)15) の学説 (dynamic receptor theory) である。 noradrenaline・受容体絬合模型を 図 1 に示す。，アミン側鎖の $\mathrm{N}^{+}$と ATP 末端り ン酸基の O- 間のイオン結合が作用発現に重要 である。その結果, 受容体分子の conformation 変化が括こり ${ }^{15)}, \mathrm{Ca}^{++}$は細胞に流入する， $\mathrm{N}^{+}$ につく置換基が大きい場合にはイオン結合は妨 げられ作用が発現し難くなる。膜 $\mathrm{Na}^{+}, \mathrm{K}^{+}-$ activated ATPase はATP を分解し， $\mathrm{N}^{+} \cdot \mathrm{O}^{-}$の イオン結合を解消するが，その際発生するエネ ルギーないし ATP 減少が $\mathrm{Ca}^{++}$の動きを変化 する要因の一つとなるであろら。受容体膜 ATPase が作用するのに $\mathrm{Ca}^{++}$が必要である. adrenaline 収縮の際，摘出腸間膜動脈 ATP お よび creatine phosphate が減少すると報告され ている ${ }^{16)}$. 大動脈 homogenate の microsome 分 画を用いた実験で, Verityと Bevan'17) は $\mathrm{Mg}^{++}$ ATPase の中に $\mathrm{Na}^{+}, \mathrm{K}^{+}$によって活性化され ouabain によって失活する ATPase の存在を証 明し得なかった。しかし，Wolowykたち18)は同

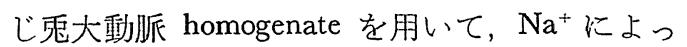
て活性化され ouabainによって影響をらけない ATPase と, $\mathrm{Na}^{+}+\mathrm{K}^{+}$によって活性化され ouabainによって失活される ATPase の存在を認 めている，後者の活性はさきに Bonting たち199 の発表したごとくきわめて低い，adrenaline $\alpha$-受容体刺激作用発現之, $\mathrm{Na}^{+}$, $\mathrm{K}^{+}$-activated ATPase の活性化ないし膜 ATP の分解との因果関係が究明されて 始めて Belleau 学説に刘する適切な評価 が下せることになる。ただし，膜 ATPase は想定された受容体機構以外に $\mathrm{Na}^{+}$を 細胞からく又出与機棈 $\left(\mathrm{Na}^{+}\right.$pump-後述) にも関与しているため問題の解析は複雑 になる。

2. 平滑筋の H-meromyosin 結合 ATP の䤂素的加水分解を促進して筋収縮を抏こすと する Bloom と Goldman の説20)である。すなわ ち、アミンの作用点が紐胞内にあるとする考え である. ATPase の触煤によって抗こるこの分 解は $\mathrm{Ca}^{++}$の介在によって actin ・ myosin 間の bridge を解消し，両 filament の overlapping を 可能にするという。この説は $\mathrm{K}^{+}$脱分極平滑筋 を用いて得られた以下の実験成績21) 23) によっ て支持岂れる。（a） adrenaline収縮は細胞謨電

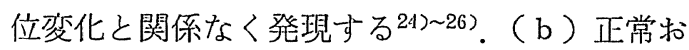
よび脱分極平滑筋の adrenaline 収縮は拮抗薬に よって同様同程度に拮抗される。（c） adrenaline 収縮は $\mathrm{Ca}^{++}$の存在に依存与る。（d ） $\mathrm{Ca}^{++}$ 抢よび adrenaline 収縮は完全に相加的である。

Bloom たちは細胞内受容体説を主張しながら も，膜受容体の存在を否定していない。膜の adrenaline 受容体として膜 ATPase を考元てい る.

3. Robison たち27)の adenyl cyclase 仮説であ る. adenyl cyclase は後述のごとくはじめ $\beta$-受 容体として提案され，その裏付け実験が数多く 行なわれてきた27) 29). 彼らは $\alpha$-受容体機構を $\beta$-受容体のそれと同じ基盤で説明しようとして いる。宁なわち， $\alpha$-受容体刺激楽は adenyl cyclase の别の regulatory subunit ${ }^{27)}$ と結合して 同酵素活性を低下または $\beta$-受容体刺激の場 命 とは違った compartment で同酵素を活性化する ことによって反応を若起するという， $\alpha$-受容体 刺激は膵臓，膀胒 ${ }^{30}$ 小よび皮膚 ${ }^{31)}$ 組織内 cyclic AMP 量を減少すると報告されている。他方， Bartelstone たも ${ }^{32}$ は組織 cyclic AMP の增加が 
ラット大動脈の noradrenaline 収縮に関与 することを示览している。

4. Meyer たち ${ }^{33)}$ は筋 phosphorylase b kinase $か ゙ \mathrm{Ca}^{++}$存在下，蛋白因子(KAF， kinase activating factor)によって活性化さ れ，筋 glycogen 分解が促進されることを 見出した。この kinase 活性化過程は cyclic AMP によるそれとは異なるものである. Belleau ${ }^{15)}$ は蛋白因子-Ca ${ }^{++}$系が $\alpha$-受容体 に関連する可能性を示唆した。 glycogen 分 解促進が細胞内の $\mathrm{Ca}^{++}$利用度を增大して 筋収縮をひき沶こす。

\section{(B) adrenaline $\beta$ 受容体学説}

Bloom と Goldman ${ }^{20)}$ は $\beta$-受容体として ATP·adenyl cyclaseを想定した. catechol の -OH が $\mathrm{Mg}^{++}$キレートの役割を果す結果, 側 鎖の $\mathrm{N}^{+}$が ATP の最内側りン酸基の $\mathrm{O}^{-}$に接 近し, ring 形成 (ATP $\rightarrow$ cyclic AMP) を容易に する。結合の模型を図 2 に示す。

adenyl cyclase が $\beta$-受容体そのものであると 寸る Robison たち27)の説は，心矨収縮力に関 する限りこれを支持する知見が数多く報告さ れ29)現在一般に認容されつつある。しかし，心 臓の $\beta$ 一受容体刺激によって莠起される律動数增 加作用が adenyl cyclase 活性化を介するとの証 拠は得られていない. 挋肺動挀では theophylline が isoproterenol の膜過分極作用を增強 し ${ }^{34)}$, dibutyryl cyclic AMP が膜を過分極すると報告 されている35)，渦分極には $\mathrm{Na}^{+}$pump 刺激が関 与するといら ${ }^{34)}$. しかし, adenyl cyclase 活性 化が血管，心臟その他諸藏器の $\beta$-受容体刺激効 果発現の火つけ役になるとするこの説で説明し 難い幾つかの事実が知られている。例えば， (1) $\beta$-溂激兮心筋収縮力を增強し ${ }^{36)}$ （扣そらく 細胞内遊離 $\mathrm{Ca}^{++}$量を增加），腺分泌を六進す

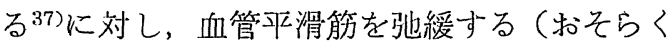
$\mathrm{Ca}^{++}$量減少 ${ }^{38)}$ ) こと，(2) practolol (ICI 50172) は心欌に拈ける $\beta$ 一刺激効果を遮断するが血管の それに影響をおよぼさないことから $\beta$-受容体機 構が心臟と血管では異なるであろうと考えられ ることならびに (3) 血管の adenyl cyclase 活性 は isoproterenol の高濃度適用によって影響をう

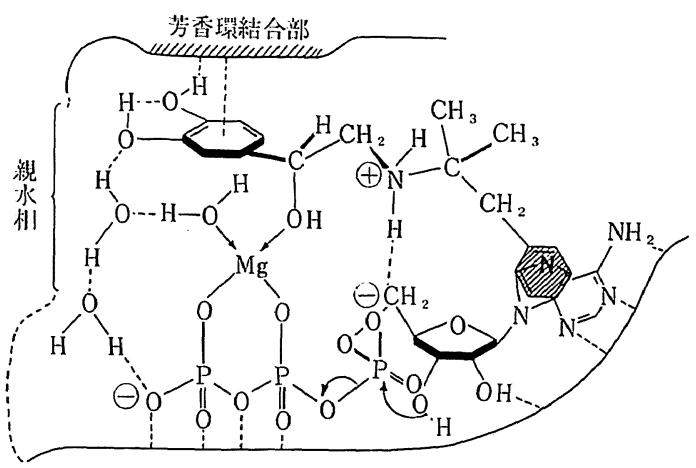

図 2 adrenaline $\beta$-受容体模型 ${ }^{15)}$

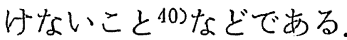

(C) 血管 adrenaline 受容体の抽出之同定

最近，受容体そのものの抽出と同定に注意が 向けられている。 Dikstein'11) は ${ }^{3} \mathrm{H}$-dibenamine が我大動挀の cephaline 分画と結合し，その絬 合は adrenaline 前投与によって炏げられること から, phospholipid が adrenaline 受容体頪似の 性質を有することを城告した。 その後, Young たち ${ }^{42)}$ はより詳細な実験を行ない， ${ }^{14} \mathrm{C}$-dibenamine の $1 / 3$ は大動脈の脂質抽出液中に存在す るが， cephaline が dibenamine の受容物質であ るといら証拠は得られなかったと結 論してい る。この面からの恰討が受容体の同定に貢献与 ることを疑わない，しかし，薬物と結合能を有 する化学物質を抽出するだけでは問題を解決し たことにならない，その物質が薬物と結合して 細胞膜, 細胞括よび藏器㙨能を変化一正るとの碓 認が必要である。

\section{II. 細胞膜興奪}

血管平滑筋緗胞膜静止電位は神経，骨格筋拉 よび心筋のそれと同様に獏内外 $\mathrm{K}^{+}$濃度差なら びに膜の $\mathrm{K}^{+}$透過性に依存する43)。また，血管 平滑筋では静止時の $\mathrm{Na}^{+}$膜透過性が高く44)45), $\mathrm{Na}^{+}$の影響を無視できない，心筋に扣いても平 滑筋頪似の性質を有する洞房・房室結節細胞の $\mathrm{Na}^{+}$膜透過性の高いことが示唆されている46). 流入 $\mathrm{Na}^{+}$を浱度勾配に抗して排出与る $\mathrm{Na}^{+}$ pump の活性 ${ }^{41) 45)}$ もまた静止電位を規定する一 因子となる。 $\mathrm{Na}^{+}$pump の刺激は膜を過分極与 る、 $\mathrm{Cl}^{-}$の動きが問題にならない程度であれば 


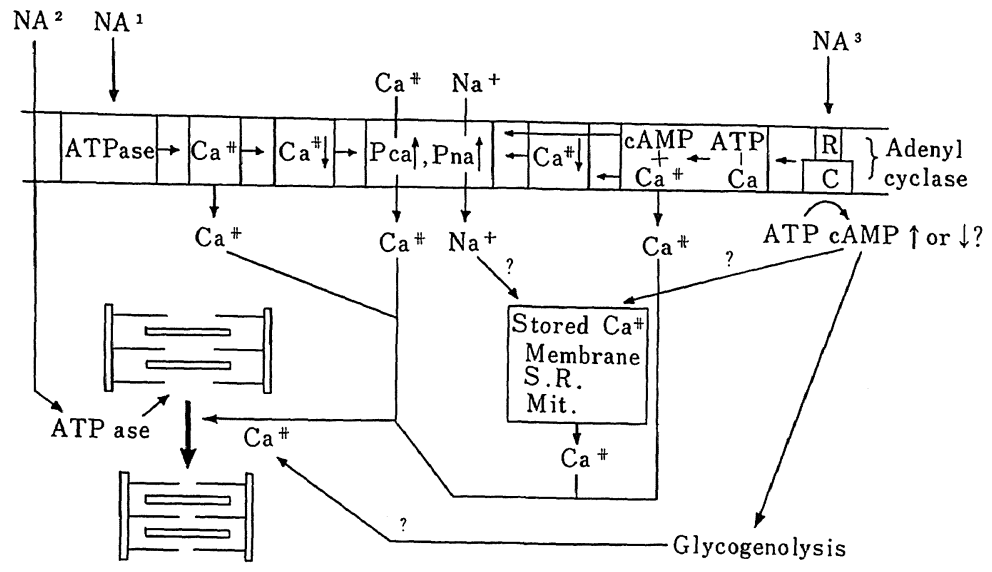

図 3 noradrenaline 作用模式図

図上方帯状の部分は細胞膜を示す. NA は noradrenaline, NA 右肩の数字 は $\alpha$-受容体説 (12 頁) の各項目番号を示す. S.R. は笳小胞体，Mit. は mitochondria.

膜静止電位 (Em) は近似的に次の式によって算 出される43).

$$
\mathrm{Em}=\frac{\mathrm{RT}}{\mathrm{F}} \ln \frac{\mathrm{P}_{\mathrm{Na}}[\mathrm{Na}]_{0}+\gamma \mathrm{PK}_{\mathrm{K}}[\mathrm{K}]_{0}}{\mathrm{P}_{\mathrm{Na}}[\mathrm{Na}] \mathrm{i}+\gamma \mathrm{PK}[\mathrm{K}] \mathrm{i}}
$$

ここで， Rは気体常数， $\mathrm{T}$ は絶対温度， $\mathrm{F}$ は Faraday 常数，PNa，PK はそれぞれ $\mathrm{Na}^{+}, \mathrm{K}^{+}$膜 透過性， $r$ は濃度勾配にさからって $\mathrm{K}^{+} 1$ 分子 が細胞内にとりこまれる際これに couple して 細胞より排出される $\mathrm{Na}^{+}$の分子数を示す。

活動電位波型は動物の種頼ならびに血管の大 小と種頪によって龧しく異なる。例えば，活動 電位幅は 40～50msec (救47)よびラット48) 細 小動脈) から15秒 (カメ大動脈 ${ }^{49}$ ) におよぶ. 活 動電位発生に直接関係するイオンは $\mathrm{Na}^{+}$とも $\mathrm{Ca}^{++}$とも考光られるが明らかでない。息腸間 膜静脈の活動電位は tetrodotoxin によって影響 をうけないと報告50)されているが，この事実の みから $\mathrm{Na}^{+}$の関与を除外できない。心臓の洞 房結節 pacemaker 活動電位もまた tetrodotoxin に抵抗性を示す51) (著者未発表) が, 電位発生に $\mathrm{Na}^{+}$が主役を演じることを示唆する報告は少な 〈ない52) 54)， $\mathrm{Ca}^{++}$除去栄養液中でも血管平滑 筋細胞が高頻度の活動電位を発生すること融55) および $\mathrm{Ca}^{++}$除去によって消失した活動電位が noradrenaline によって回復する事実 ${ }^{56)}$ は，むし ろ $\mathrm{Na}^{+}$の関与を積極的に支持するものであろ う。モルモット taenia coli では $\mathrm{Ca}^{++}$が活動電
位発生の主役を演じると報告されている57).

薬物適用ないし筷養液のイオン組成（特に $\mathrm{K}^{+}$) 変化はしばしば膜静止電位および活動電位 に影響をおよぼす。通常, 静止電位の減少（す なわち脱分極), 活動電位の発生ならびに 活 動 電位覑度の増加は収縮に関連し, 過分極および 活動電位頻度の減少は弛緩につながる43)。栄養 液の $\mathrm{K}^{+}$を増量すると平滑筋細胞膜は持続性に 脱分極し, 細胞への $\mathrm{Ca}^{++}$流入は增加し ${ }^{58)}$, 筋収 縮が括こる，noradrenalineは活動電位の頻度を 增加し，持続性の脱分極を焤起して筋収縮をお こす59)60)。筋同様膜の $\mathrm{Na}^{+} お よ ひ ゙ ~ \mathrm{Ca}^{++}$透過 性增大が考えられるが，他方， $\mathrm{Na}^{+}$pump 刺激 （過分極をおこす）の可能性が示唆されてい る43)。また， noradrenaline はラット大動脈の $\mathrm{K}^{+}$透過性を增大乙膜を過分極するが，この作 用は $\alpha$-受容体遮断薬である phentolamine によ って拮抗されるとの報告 ${ }^{61)}$ がある。他方，薬物 適用によって膜電位変化を扣こすことなしに (non-electrical process) 膜の $\mathrm{Ca}^{++}$透過性を増 大し，膜 $\mathrm{Ca}^{++}$の遊離を拈こすことが知られて いる24)25)56)59/62)63) (pharmacomechanical coupli$\left.\mathrm{ng}^{59)}\right)$.

薬物一受容体結合と $\mathrm{Ca}^{++}$ない乙 $\mathrm{Na}^{+}$動態の 関係を図 3 に示す。noradrenaline は受容体分子 の conformation を变化し14)20331)，膜の物理的・ 化学的性質を变化する.この変化が膜結合 $\mathrm{Ca}^{++}$ 
の遊離を促進し, 膜 $\mathrm{Ca}^{++}$を減少する結果 $\mathrm{Ca}^{++}$ の膜安定化作用を減少する。 そのために膜を通 過する $\mathrm{Ca}^{++}$(および $\mathrm{Na}^{+}$) の passive な流れ は容易になり，濃度勾配に従ってイオンは細胞 外より内へ移動すると Somlyo たち ${ }^{43}$ は推論し ている，心䇗において $\mathrm{Ca}^{+++}$が膜安安定化し， 陽イオン (特に $\mathrm{Na}^{+}$) の passive な膜透過を抑 制する64) ことか判断して, 血管平滑筋細胞膜 $\mathrm{Ca}^{++}$が $\mathrm{Ca}^{++}$扣よび $\mathrm{Na}^{+}$の膜通過を限定する 可能性は十分に考えられる。一方, noradrenaline が血管においても adenyl cyclase を活性化 するとすれば ATP $\rightarrow$ cyclic AMP 反応が促進さ れることになる。 Rasmussen たち ${ }^{65)}$ は cyclic AMP は $\mathrm{Ca}^{++}$の膜透過性を規定する重要な因 子であると述べている。 また, cyclic AMP の $\mathrm{Ca}^{++}$キレート作用が ATP のそれに比べ著しく 弱(65)ことから ATP $\rightarrow$ cyclic AMP 反応促進は 膜 ATP 結合 $\mathrm{Ca}^{++}$の遊離とその減少をもたら すであろら。

\section{III. 血管収縮}

血管平滑筇収縮および弛緩は細胞内遊離 $\mathrm{Ca}^{++}$量の增減に伴って発現する ${ }^{43}$. 遊離 $\mathrm{Ca}^{++}$ の大部分は源を細胞外液に，一部は形質膜，筋 小胞体技よび mitochondriaに求めることができ る（図 3 ），ただし，血管平滑筋の筋小胞体の 発達は哺乳動物において著しく悪いとされてい る35). 薬物ないし $\mathrm{K}^{+}$は $\mathrm{Ca}^{++}$の細胞流入と細 胞からの流出ならびに細胞膜および細胞内結合 $\mathrm{Ca}^{++}$の遊離と再結合に直接・間接に影響して $\mathrm{Ca}^{++}$濃度を変化する。 $\mathrm{K}^{+}$収縮には $\mathrm{Ca}^{++}$流入 が関与し, noradrenaline, histamine, acetylcholine および angiotensin 収縮には膜 $\mathrm{Ca}^{++}$の遊離促 進と $\mathrm{Ca}^{++}$流入増加が関与する。 papaverine の 平滑筋弛緩作用には $\mathrm{Ca}^{++}$流入減少之細胞膜扩 よび細胞内貯臟部への $\mathrm{Ca}^{++}$とりこみ促進が関 与するといわれる66) 68).

血管平滑筋収縮の骨格筋収縮との相違は次の 通りである。（1）収縮は刺激薬物用量の增加之 ともに段階的に增大し，明らかな用量一作用の 関係が得られる。（2）薬物の収縮作用と膜静止 電位ないし活動電位頻度との間に定量関係が見
出せない、時に, 膜電位の変化なしに収縮の出現 することは既述の通りである (pharmacomechanical coupling).（3）最大収縮高が薬物の種類 によって異なる59). Somlyo たち43) はその原因 として槳物の膜 $\mathrm{Ca}^{+++}$遊離能の相違をあげてい る.

\section{IV. 内因性および外来 noradrenaline の血管作用}

血管平滑筋は通常交感神経節後線維 (adrenaline 作動性線維) によって支配され, choline 作動性線維の関与は一部の血管を除いて無視し 得る程度である。溃光組織化学によって血管壁 の noradrenaline 含有神経線維の分㭁を調べる と, 神経の大多数は外膜・叫膜境界部, 一部は 中膜中央より外側部を支配していることがわか

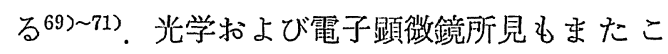
の事実を裏づけしている43)，神経由来の noradrenaline が主として外膜・中膜境界部に遊離 されるに刘し，外来 noradrenaline は主として 内膜面より作用することになり，雨者の作用の 相違, 薬物作用に対与る支配神経の関与, 受容 体ならびに分解酵素の局在, noradrenaline の組 織内渗透などが問題としてとり上げられる理由 はここにある。

Furchgott の記蛓72) 以後摘出血管平滑筋絮張 に㧍よぼす交感神経刺激の影響を検討する手段 の一つとしてしばしば transmural stimulation ${ }^{73)}$ が用いられてきた。大・非血管にしか邂用でき ない不便さはむるが，きわめて単純化した平滑 筋の反応を神経機能との関連において分析する に有用な手段と言える，血管条片を電気的に刺 激与る場合，間接刺激（神経刺激）を直接溂激 (筋刺激) と区別するには以下の楽理学的方法 を用いるのが便利である。（1） adrenaline $\alpha$-受 容体遮断楽および atropine で反応が遮断される かどうか, (2) bretylium, TM 10, botulinus toxin など伝達物質遊離阻害剤の影響はどらか， (3) tetrodotoxin の低濃度 $\left(10^{-7} \mathrm{M}\right.$ 程度. $10^{-6} \mathrm{M}$ 以上になると筋収縮が影響をうげる技それがあ る）によって遮断されるか，(4) reserpineない ᄂ 6-hydroxydopamine ${ }^{73)}$ (chemical sympathect- 


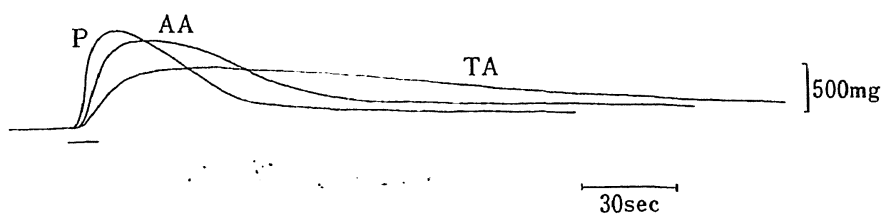

図 4 雭血管条片 transmural stimulation

$\mathrm{P}$ は肺動哌， $\mathrm{AA}$ は上行大動脈，TA は胸部大動哌を示す。記録直 下の横線は刺湤（10秒間，20/sec）適用を示す71).

omy ${ }^{74)}$ ) 生体位処置によって noradrenaline 量を 著明に減少した血管に拈いて反応はどうか, （5） $\mathrm{Ca}^{++}$除去栄養液に浸清した標本ではどう か(外来 noradrenaline の作用は $\mathrm{Ca}^{++}$除去に よって軽度抑制されるに過ぎない)，（6）冷 却 眝臓 4〜 7日の血管75)ではどらか(この操作は 平滑筋の noradrenaline 感受性を增強与るが, tyramine および nicotine に対する感受性を著明 に低下する。組織 noradrenaline 量は減少す る ${ }^{76)}$ ) などである。刺激によって弛緩が得られ れば $\beta$-遮断薬および ouabain の影響を検討する 必要がある。匝上行大動脈, 胸部大動脈および 肺動脈条片に関する限り，直接ならびに間接刺 激を区別する重要な因子は刺激幅である70)72). $0.3 \mathrm{msec}$ 以下の刺激幅では（頻度 $5 \sim 20 / \mathrm{sec}$ ) 直接刺激は常に無視し得る程度である。 $\mathrm{Su}$ と Bevan77) は最近肺動脈条片の transmural stimulation に superfusion の手技を加えて，刺激に呼 応して $\mathrm{H}^{3}$-noradrenaline の大量が遊離し筋が収 縮することを示した。 tetrodotoxin は両者を遮 断する. phenoxybenzamine は潅流液中の amine 量を増加するが筋収縮を遮断する。

transmural stimulation による反応はしばしば 外来 noradrenaline 作用と異なる。（1）血管の 種類によって神経刺激に対する反応が著しく異 なる70)。乘肺動脈拈よび上行大動脈条片は刺激 に対して強い一過性の収縮でもって応じるが, 胸部大動脈の収縮は弱く持続が長い，図 4 にそ の特徵を示す。上腸間膜動脈条片は同条件の刺 激に反応しない，血管の部位による noradrenaline 感受性の相違はそれ程著明ではない78)。む しろ，上腸間膜動脈の noradrenaline 感受性は 高い79). 組織化学的に血管壁の noradrenaline 䖝光が上行大動脈㧍よび肺動脈に多く，心藏か
らの距離が遠くなるに従って減少する傾向があ るが，上腸間膜動脈壁にもな拉 noradrenaline 螢光の存在を認める。神経刺激反応態度の血管 種類による相違は，平滑觔側の被制激性ならび に神経側の noradrenaline 含有量の相違に加え て, noradrenaline の局在㧍よび生理機能発現に 対する内因性 noradrenaline の貢献度の相違な ぞにもとづくものであろら。犬では腸間膜, 腎 および肺動脈条片は神経刺激に応じるが，冠動 脈条片は同条件の刺激に応じない。ラット大動 脈条片は刺激に. 応じない.ラット大動脈に noradrenaline 含有量の少ないことが化学的80) ならびに組織化学的に認められている（服部， 森, 未発表). 大動脈条片の noradrenaline 感受 性はラットで最も強く, 鬼, モルモット，猫の 順に減少する80).（2）持続的神経刺激によって 萡起される上行大動脈および肺動脈条片の最大 収縮は， noradrenaline によるそれのせいぜい $1 / 2$ である。刺激時の最大収縮は noradrenaline $10^{-7} \sim 10^{-6} \mathrm{M}$ の収縮にひってきする，血管支配 神経の特異性によるものかも知机ない（3）神 経刺激（2１0秒間）による収縮は通常 10 分 以内に消失し，安定した収縮反応を長時間に わたってくり返し再現し得る。緊張上昇の過 程は平滑筋の noradrenaline 感受性と遊離 noradrenaline 量に依存し, 緊張の回復過程は主 として noradrenaline 不活性化機構によって影 響をらける81). 不活性化機構として amine の 神経への reuptake ならびに酵素 (monoamine 酸化酵素および catechol-O-methyl transferase) による分解が考兄られる。従来の報告では noradrenaline 収縮の变化のみから平滑筋反応性 を諭じてきた。 transmural stimulation の併用は 自律神経薬の血管平滑筋作用機序解析の一助之 
なろう。（4）現在の刺激方法では 動脈（犬冠 動脈など) 条片に弛緩反応を薏起しない。 Hughes とVane82) は鬼門脈条片に transmural stimulationを適用して弛緩を認めている。 tetrodotoxin 適用によって消失し， $\beta$-遮断薬拈 よび hyoscine が無効であったことから，神経 刺激によって non-adrenergicかつnon-cholinergic の化学物質が起離されたとしている。この物質 が adenosine 誘導体であるとは考光難い。$$
\text { むすび }
$$

薬物受容体の存在は広く楽理学者, 生理学者 を始め薬物の作用機序解明に興味をいだく研究 者・臨床家の認容するところであるが，本稿に 述べたごとくその実体は不明である。ここに紹 介した adrenaline 受容体学説の全てはこれ迄の 多数の知見をもとに帰納されたものであって， 薬物の生体作用をほぼ矛盾なく説明し得るもの として認容されている. 今後も実験所見の增加 に伴って受容体学説の訂正と新規提案がくり返 され，受容体研究のためのより妥当な方向性が 示されることになろら。一方, 受容体物質の単 離がより優れた技術と斬新な発案によって進展 することを願らものである。機能研究所見より 受容体として帰納された化学物質が，化学的に 抽出単離された物質に一致する時こそわれわれ が受容体の全貌を知る時であり，この事態に一 日も早く近づることが現在われわれに果せら れた使命であると考える。

\section{文献}

1) Goodman, L.S. and Gilman, A.: The Pharmacological Basis of Therapeutics. Macmillan, New York, 1970.

2) Clark, A.J.: The Mode of Action of Drugs on Cells. E. Arnold \& Co., London, 1933.

3）岳中典男, 川越哲美：代謝, 8(4)；244, 1971.

4) Ariëns, E. J.: Molecular Pharmacology. Academic Press, New York, 1964.

5) Furchgott, R. F.: Ann. Rev. Pharmacol., 4; 21, 1964.

6) Ehrenpreis, S., Fleisch, J.H. and Mittab, T. W.: Pharmacol. Rev., 21; 131, 1969.

7) Ahlquist, R. P.: Am. J. Physiol., 153; 586, 1948.
8) Dale, H.H.: J. Physiol. 34; 163, 1906.

9) Nickerson, M. and Goodman, L. S.: J. Pharmacol. Exp. Ther., 89; 167, 1947.

10) Nickerson, M. and Hollenberg, N.K.: Physiological Pharmacology. Academic press, New York, 1967.

11) Powell, C.E. and Slater, I. H.: J. Pharmacol. Exp. Ther., 122；480, 1958.

12) Black, J. W., Crowther, A.F., Shanks, R.G., Smith, L. H. and Dornhorst, A. C.: Lancet, 1; 1080, 1964.

13) Stanton, H.C., Kirchgessner, T. and Parmenter, K.: J. Pharmacol. Exp. Ther., 149; 174, 1965.

14) Belleau, B.: Advan. Drug Res., 2; 89, 1965.

15) Belleau, B.: Ann. N.Y. Acad. Sci., 139; 580, 1967.

16) Beviz, A., Lundholm, L., Mohme-Lundholm, E. and Vamos, N.: Acta physiol. scand., 65; 268, 1965.

17) Verity M.A. and Bevan, J.A.: Biochem. Pharmacol., 18; 327, 1969.

18) Wolowyk, M.W., Kidwai, A.M. and Daniel, E.E.: Canad. J. Biochem., 49; 376, 1971.

19) Bonting, S.L., Simon, K.A. and Hawkins, N. M.: Arch. Biochem. Biophys., 95; 416, 1961.

20) Bloom, B. M. and Goldman, I. M.: Advan. Drug. Res., 3; 121, 1966.

21) Evans, D. H. L., Schild, H. O. and Thesleff, S.: J. Physiol., 143; 474, 1958.

22) Schild, H. O.: Cida Foundation Symposium on Adrenergic Mechanims. Churchill, London, 1960.

23) Edman, K.A.P. and Schild, H.O.: J. Physiol., 169; 404, 1963.

24) Waugh, W. H.: Circ. Res., 11; 264, 1962.

25) Waugh, W. H.: Circ. Res., 11; 927, 1962.

26) Keatinge, W.R.: J. Physiol., 194; 169, 1968.

27) Robison, G.A., Butcher, R.W. and Sutherland, E.W.: Ann. N.Y. Acad. Sci., 139；703, 1967.

28) 阿部 㸃: 代謝, 臨洔增刊号 (cyclic AMP) p. 129, 1971.

29) 矢崎義雄, 藤非潤：代敦, 臨時增刊号 (cyclic AMP) p. 137, 1971.

30) Turtle, J.R. and Kipnis, D. M.: Biochem. Biophys. Res. Commun., 28; 797, 1967.

31) Robison, G.A., Butcher, R.W. and Sutherland, E. W.: Fundamental Concepts in Drug-Receptor Interactions. p. 59, Academic press, New York, 1970. 
32) Bartelstone, H.J., Nasmyth, P.A. and Telford, J.M.: J. Physiol., 188; 159, 1967.

33) Meyer, W.L., Fischer, E.H. and Krebs, E.G.: Biochemistry, 3; 1033, 1964.

34) Somlyo, A. V., Haeusler, G. and Somlyo, A. P.: Fed. Proc., 29; 613, 1970.

35) Somlyo, A.P. and Somlyo, A.V.: Pharmacol. Rev., 22; 249, 1970.

36) Sutherland, E.W., Robison, G.A. and Butcher, R.W.: Circulation, 37; 279, 1968.

37) Douglas, W. W.: Brit. J. Pharmacol. Chemother., 34; 451, 1968.

38) Bohr, D.F.: Ann. N. Y. Acad. Sci., 139; 799, 1967.

39) Dunlop, D. and Shanks, R. G.: Brit. J. Pharmacol. Chemother., 32; 201, 1968.

40) Schonhofer, P.S., Skiclmore, I.F., Forn. J. and Fleisch, J.H.: J. Pharm. Pharmacol., 23; 28, 1971.

41) Dikstein, S. and Sulman, F.C.: Biochem. Pharmacol., 14; 881, 1965.

42) Young, M. S., Parulekar, M. R., Wright, J. and Marks, G. S.: Biochem. Pharmacol., 15; 1185, 1966.

43) Somlyo, A.P. and Somlyo, A.V.: Pharmacol. Rev., 20; 197, 1968.

44) Garraham, P., Villamil, M.F. and Zadunaisky, J.A.: Am. J. Physiol., 209; 955, 1965.

45) Hagemeijer, F., Rorive, G. and Schoffeniels, E.: Life Sci., 4; 2141, 1965.

46) Trautwein, W. and Kassebaum, D.G.: J. Gen, Physiol., 45; 317, 1961.

47) Funaki, S.: Proc. Jap. Acad., 34; 534, 1958.

48) Steedman, W. M.: J. Physiol., 186; 382, 1966.

49) Roddie, I.C.: J. Physiol., 163; 138, 1962.

50) Holman, M. E., Kasby, C. B., Suthers, M. B. and Wilson, J.A. F.: J. Physiol., 196; 111, 1968.

51) Yamagishi, S. and Sano, T.: Proc. Jap. Acad., 42; 1194, 1966.

52) Trautwein, W.: Pharmacol. Rev., 15; 277, 1963.

53) Toda, N. and West, T. C.: Am. J. Physiol., 212; 416, 1967.

54) Toda, N.: J. Physiol., 169; 677, 1968.

55) Keatinge, W.R.: J. Physiol., 194; 183, 1968.

56) Johansson, B., Jonsson, O., Axelsson, J. and Wahlstrom, B.: Circ. Res., 21; 619, 1967.

57) Goodford, P.J.: J. Physiol., 192; 145, 1967.

58) Briggs, A.H.: Am. J. Physiol., 203; 849, 1962.
59) Somlyo, A.W. and Somlyo, A.P.: J. Pharmacol. Exp. Ther., 159; 129, 1968.

60) Nakajima, A. and Horn, L.: Am. J. Physiol., 213; 25, 1967.

61) Rorive, G., Hagemeijer, F. and Schoffeniels, E.: Arch. int. pharmacodyn. ther., 167; 265, 1967.

62) Hrdina, P. and Garattini, S.: J. Pharm. Pharmacol., 19; 667, 1967.

63) Keatinge, W.R.: Circ. Res., 18; 641, 1966.

64) Weidmann, S.: J. Physiol., 129; 568, 1955.

65) Rasmussen, H. and Tenenhouse, A.: Proc. N. A.S., 59; 1364, 1968.

66) Imai, S. and Takeda, K.: J. Pharmacol. Exp. Ther., 156; 557, 1967.

67) Tashiro, N. and Tomita, T.: Brit. J. Pharmacol. Chemother., 39; 608, 1970.

68) Carpenedo, F., Toson, G. C., Furlanut, M. and Ferrari, M.: J. Pharm. Pharmacol., 23; 502, 1971.

69) Cech, S. and Dolezel, S.: Experientia, 23; 114, 1967.

70) Shibata, S., Hattori, K., Sakurai, I., Mori, J. and Fujiwara, M.: J. Pharmacol. Exp. Ther., 177; 621, 1971.

71) Toda, N., Usui, H. and Mori, J.: Jap. J. Pharmacol., 22(1)；印刷中, 1972.

72) Furchgott, R. F.: Pharmacol. Rev., 7; 183, 1955.

73) Paterson, G.: J. Pharm. Pharmacol., 17; 341, 1965.

74) Porter, C.C., Totaro, J.A. and Stone, C. A.: J. Pharmacol. Exp. Ther., 140; 308, 1963.

75) Thoenen, H. and Tranzer, J.P.: Arch. Pharmak., 261; 271, 1968.

76) Shibata, S.: Circ. Res. 24; 179, 1969.

77) Su, C. and Bevan, J. A.: J. Pharmacol. Exp. Ther., 172; 62, 1970.

78) Altura, B.M. and Altura, B.T.: Eur. J. Pharmacol., 12; 44, 1970.

79) Bevan, J. A. and Osher, J. V.: J. Pharmacol. Exp. Ther., 150; 370, 1965.

80) Maling, H.M., Fleisch, J.H. and Saul, W.F.: J. Pharmacol. Exp. Ther., 176; 672, 1971.

81) Toda, N.: J. Pharmacol. Exp. Ther., 179; 198, 1971.

82) Hughes, J. and Vane, J.R.: Brit. J. Pharmacol. Chemother., 39; 476, 1970. 